\title{
UNGES DIALEKTBRUG I BYGDEN SANDUR PÅ FÆRØERNE
}

\author{
JÓGVAN Í LON JACOBSEN \\ Fróðskaparsetur Føroya (Færøernes Universitet)
}

\section{ABSTRACT}

Denne artikel drøfter dialektændringer hos unge i bygden Sandur på Sandoy på Færøerne. Artiklen bygger på data, som blev indsamlet på øen den 15. november 2019. Feltarbejdet blev udført af en gruppe studerende på Institut for færøsk på Færøernes Universitet som en del af studieemnet dialektologi under ledelse af denne artikels forfatter. Informanterne er skoleelever i hhv. 3.-4. klasse og 9. klasse. Ved at vælge skoleelever kan vi få indblik i, hvordan dialekten har det blandt de yngste sprogbrugere. Af pladshensyn undersøges kun tre lingvistiske variabler i denne artikel: (i) Variation mellem bestemt og ubestemt form af ord for familjemedlemmer, f. eks. dialektformen mamman 'moren' og den centralfærøske ${ }^{1}$ form mamma 'mor', (ii) Personlige og possessive pronominer i 1 . og 2. pers. flertal i oblik kasus, f. eks. dialektformen [o:gon], skrevet <okum> 'os' og den centralfærøske form [ $\left.\mathrm{o}^{\mathrm{h}} \mathrm{k}: \mathrm{on}\right]$, skrevet <okkum>, (iii) Udtalen af kort ó med dialektvarianten [o] og den centralfærøske variant [œ], f. eks. [folk] og [fœlk], skrevet <fólk> 'folk'. Den første variabel viser en tydelig tendens til dialektændring, da den ubestemte centralfærøske standardform er langt mere frekvent end den bestemte dialektform. Brugen af pronominer viser stor variation, hvor de lokale former står stærkt i den yngste aldersgruppe. Brugen af kort ó viser også stor variation, men her ser vi den samme tendens som ovenfor for variabel 2, at de yngste elever i højere grad har den lokale [o]-udtale, mens variationen hos de ældste elever er langt større. I artiklen vil der blive henvist til en undersøgelse af sandoydialekten fra 2005 (Johannesen 2005).

\section{[1] BAGGRUND OG HYPOTESE}

Efterårssemestret 2019 havde denne artikels forfatter et kursus i dialektologi på Institut for færøsk på Færøernes Universitet. En del af kurset bestod i, at de studerende skulle ud at lave feltarbejde i bygden Sandur på Sandoy på Færøerne

[1] Termen centralfcerøsk bygger på udtalen omkring hovedstaden, Tórshavn. Termen standardfcerøsk anvendes med samme betydning. Men her må vi huske på, at standardfcerøsk ikke bygger på en officielt anerkendt udtalenorm. 
(se kortet nedenfor). I fællesskab forberedte vi feltarbejdet, som de studerende skulle udføre. De indsamlede alt materialet, og efterfølgende gennemgik vi dele af det indsamlede materiale i timerne. Grunden til at feltarbejde blev en del af kurset var et ønske fra de studerende om at få erfaring med og færdigheder i udførelse af praktisk feltarbejde. Efterfølgende var de yderst godt tilfreds med feltarbejdet. Undersøgelsen skal derfor tages med det forbehold, at for de fleste studerende var det første gang, de deltog i sociolingvistisk feltarbejde.

Arbejdshypotesen var, at der foregår ændringer i dialekten hos de unge på Sandoy og at disse ændringer går i retning af centralfærøsk udtale og centralfærøske former. Denne antagelse bygger på en undersøgelse fra Sandoy i 2005, som viser en sådan tendens (Johannesen 2005). Andre dialektundersøgelser på Færøerne peger i samme retning (Bugge og Jacobsen 2018). Men det viste sig efterfølgende, at det empiriske materiale fra Sandoy ikke bærer præg af ekstreme ændringer i dialekten, hvad man ellers får indtryk af hos Johannesen, jf. titlen på hendes afhandling: Sandsmál - eitt mál í broyting.

Johannesens resultater, som der henvises til i denne artikel, er fra en sociolingvistisk undersøgelse, som hun udførte i forbindelse med en BA-opgave på Institut for færøsk i 2005. Idéen med at henvise til Johannesens undersøgelse er at sammenligne vores resultater med nogle af hendes resultater for at undersøge, om tendenserne er de samme i de to undersøgelser. Mere om hendes undersøgelse ses under punkt 6 nedenfor.

\section{[2] FORMÅL}

Formålet med projektet på Sandoy var todelt: Dels at undersøge dialektbrug hos de unge og - i det omfang det var muligt - at undersøge, om der var sket ændringer i dialekten fra 2005 til 2019, dels at de studerende skulle få kendskab til at udføre praktisk feltarbejde med alt, som dertil hører af praktiske, etiske og andre forhold.

Denne artikel, som bygger på data fra Sandoy, er en kvantitativ, synkron beskrivelse af de unges dialekt, dog med enkelte tilbageblik til undersøgelsen fra 2005.

At vi valgte Sandur, var ikke tilfældigt. Årsagen var, at Johannesens studie (2005) viser en vis aldersmæssig variation af de variabler, som drøftes i denne artikel. Vores oprindelige plan var at gennemføre en undersøgelse af unges sprogbrug i virkelig tid i 2005 og 2019, men det skulle vise sig, at det lod sig ikke gøre, da der kun var to informanter fra 2005, som vi kunne identificere i den aldersgruppe, vi var interesseret i: En 12-årig dreng og en 7-årig pige, som i november 2019 var hhv. 26 og 21 år gamle og som nu bor i Tórshavn. ${ }^{2}$

Disse personers sprogbrug undersøges ikke i denne artikel. 


\section{[3] BYGDEN SANDUR}

Sandur er den største bygd på Sandoy og ligger i bugten på vestsiden af øen (se kortet). Øens samlede areal er $112 \mathrm{~km}^{2}$, og befolkningstallet i Sandur er på 500600. Bygden har sin egen folkeskole, hvor eleverne går op til og med 5. klasse, hvorefter de fortsætter på Sandoyar meginskúli, som er en centralskole for hele øens elever, fra 6. til 9. klasse. Der er færgeforbindelse mellem Sandoy og Streymoy flere gange dagligt. Om et par år er færgeforbindelsen afløst af en undersøisk tunnel. Vores dialektundersøgelse åbner således op for sammenlignende dialekt-undersøgelser i fremtiden, og især vil det være interessant at undersøge, hvorvidt tunnelforbindelsen vil påvirke dialekten på Sandoy i fremtiden.

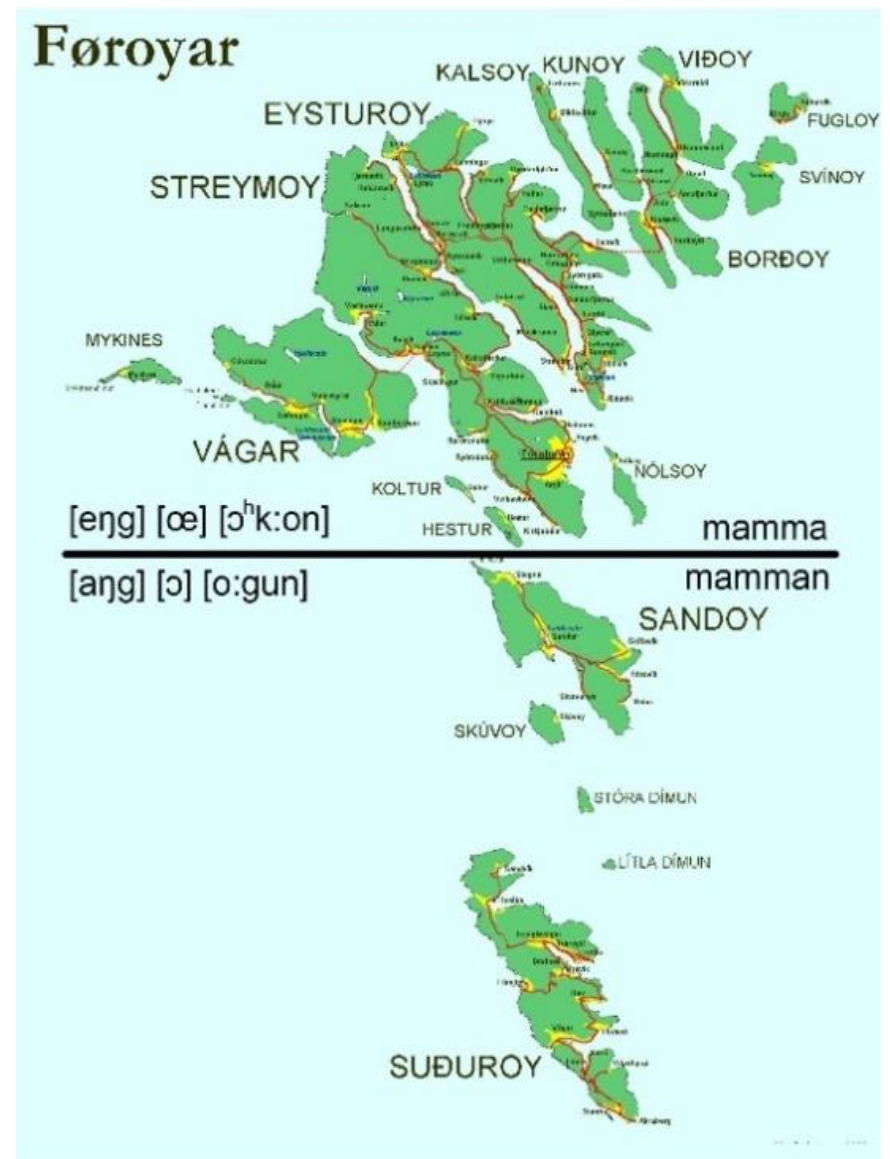

FIGUR 1: Kort af Færøerne med indlagte dialektgrænser igennem

Skopunarfjørður (ang-variablen drøftes ikke i denne artikel). 
[4] METODE

\section{[4.1] Tredelt tilgang}

Den metodiske tilgang var tredelt, dvs. at vi anvendte tre forskellige tilgange på det samme studieobjekt, som var børns og unges dialektbrug på Sandoy. Første del bestod af frie samtaler, som blev optaget på lydbånd. Samtalerne, som varede mellem 20 minutter og en halv time, blev gennemført som gruppesamtaler, hvor to og to elever sad og talte sammen. I én samtale deltog tre elever. To (i ét tilfælde tre) feltarbejdere deltog i hver samtale, hvor én interviewede og den anden sad lidt på afstand og observerede og noterede ting, som kom frem under samtalen. Feltarbejdernes opgave var ellers at tilskynde eleverne til at tale. Vi havde i forvejen formuleret nogle spørgsmål, som kunne kaste lys over de variabler, som vi var interesserede $\mathrm{i}$ at undersøge. Formålet med de frie samtaler var at få dokumenteret elevernes uformelle dagligtale. Til det formål syntes vi, at gruppesamtalen var en fordel, og det viste sig at fungere godt. Samtalerne blev ikke transkriberet. I stedet for har vi excerperet variablerne ved at lytte samtalerne igennem flere gange, ligesom vi har forsynet variablerne med tidskoder. Da samtalen var overstået, fik eleverne udleveret en liste med tyve ord, som de skulle læse op. Oplæsningen siger ikke noget direkte om dialektbrug, men kan på den anden side afdække, om der er overensstemmelse mellem elevernes uformelle dagligsprog og oplæsningen som anses som en mere formel sproglig udøvelse. En sådan sammenligning kan forklare eventuel sprogvariation. Denne pointe udnyttes ellers ikke yderligere i denne undersøgelse. Nogle af reslutaterne er gengivet $\mathrm{i}$ tabel $3 \mathrm{a}-\mathrm{b}$ nedenfor. For at forebygge at den enes oplæsning skulle påvirke den andens, var kun én elev til stede under oplæsningen. P.gr.a. uagtsomhed var i et par tilfælde begge eleverne inde under oplæsningen, men det viste sig ikke at påvirke oplæsningen. I den tredje og sidste del af undersøgelsen læste en lærer på hver skole nogle 'sætningspar' op for eleverne. Et af disse sætningspar havde følgende formulering: "Sigur tú: Mamma er til arbeiðis?" eller siger du: "Mamman er til arbeiðis"? Her ville vi undersøge, om eleverne krydsede af for dialektformen (mamman) eller standardformen (mamma). Eleverne skulle krydse af for den sætning, som de syntes var den mest naturlige. De fik at vide, at de ikke skulle tænke på, om sætningen var rigtig eller forkert, da begge sætningerne var grammatisk korrekte. Ordene i ordlisten og sætningerne i afkrydsningsspørgsmålene indeholdt de variabler, som vi forsøgte at få eleverne til at tale om i samtalerne. I tabel 1 ses fordelingen mellem disse former.

Da vi havde to og to elever, som kendte hinaden i forvejen, til gruppesamtale, blev samtalesituationen mindre formel. Denne metode fungerede ganske godt $\mathrm{i}$ 
de fleste tilfælde. I begyndelsen af samtalen oplevede vi indimellem, at eleverne ikke sagde så meget, men når de blev guidet ind på nogle samtaleemner, som fangede dem, blev samtalen mere flydende, og flere gange oplevede vi, at eleverne 'glemte', at de blev interviewet.

En af ulemperne med gruppesamtaler er, at det kan være vanskeligt at høre forskel på stemmerne, især i den yngste aldersgruppe. Men ved at lytte gentagne gange lod det sig gøre at identificere stemmerne.

\section{[4.2] Informanterne}

Vores informanter var dels elever i 3. og 4. klasse i bygdeskolen i Sandur, dels elever i 9. klasse på øens centralskole. De yngste elever var omkring ti år gamle, mens de ældre elever var omkring 15 år gamle. I bygdeskolen i Sandur var der 15 elever i 3. og 4.-klasse, og i centralskolen var der 14 elever i 9. klasse. I alt var 29 elever med i undersøgelsen. Én elev manglede i hver skole. Forældrene til børnene i bygdeskolen havde i forvejen givet os skriftlig tilladelse til, at børnene kunne deltage i undersøgelsen. Eleverne i 9. klasse gav os en skriftlig bekræftelse på, at de ville deltage i undersøgelsen. De fik at vide, at de til enhver tid kunne trække sig, hvis de måtte ønske det.

I statistiske undersøgelser vælger man et tilfældigt udvalg af informanter, som repræsenterer den population, som man vil undersøge. Population kan defineres som alle de scoringer, man ville fă, hvis alle dem, der opfylder betingelserne, blev spurgt (Reinholt Petersen 2001, s. 11). I vores undersøgelse er det årgangene, hhv. de 10-årige i bygden Sandur og de 15-årige på hele øen i 2019 , som er populationen, dvs. at der er tale om to $100 \%$ populationer. Vi undersøgte samtlige informanter, som opfyldte vores aldersmæssige betingelser på øen. Dvs. at de to årgange er repræsentative for øens ungdomsgeneration. Set fra en statistisk synsvinkel er det naturligvis en fordel at have to hele populationer med, fordi da kan man se bort fra at skulle udføre statistiske analyser af materialet for at tjekke, om resultaterne er generaliserbare. En sådan unik mulighed har man kun i små sprogsamfund.

\section{[5] LINGVISTISKE VARIABLER}

Den klassiske dialekt på Sandoy har nogle variabler, som peger sydpå, f. eks. de personlige pronominer i flertal, f. eks. [o:gon] og [ $\mathrm{t}^{\mathrm{h}} \mathrm{i}$ :gon], udtalen [a] foran velar nasal [ang] (langur, ganga) og [0]-udtale af kort ó (fólk, bóndi). På den anden side peger det lange ó udtalt som [œu:] nordpå (sól, stórur).

Historisk set har sandoydialekten været klassificeret som del af søndenfjordsmålet, dvs. dialekten syd for skopunarfjørður, se de indlagte dialektgrænser på kortet ovenfor (Petersen 1996; Weyhe 2012). 
I denne artikel undersøges tre variabler:

(i) Variabel 1:

Bestemt eller ubestemt form af ord for familjemedlemmer

(f.eks. dialektformen mamman og standardformen mamma).

(ii) Variabel 2:

Personlige pronominer i 1. og 2. pers. flertal i oblik kasus

(f.eks. dialektformen [o:gon] og standardformen [ $0^{\mathrm{h} k: \mho n]}$ ).

(iii) Variabel 3:

Udtalen af kort ó (med varianterne [o] og [œ]).

\section{[6] JOHANNESENS DIALEKTUNDERS ØgELSE FRA 2005}

Johannesens metodiske tilgang var den samme som vores: Samtaler (dog ikke i grupper), oplæsning af ord og afkrydsningsspørgsmål. Hendes undersøgelse havde et andet sigte end vores, idet hun var interesseret i sprogændring og variation både hos voksne og unge informanter. Hun interviewede 16 informanter, mest voksne og gamle. Den ældste person var en 94 år gammel mand (født i 1911) og den yngste var en 7-årig pige (født i 1998). Derudover havde hun tyve unavngivne skoleelever i 3. og 4. klasse i bygdeskolen i Sandur.

Johannesen kunne konstatere, at der var stor variation i brugen af bestemt og ubestemt form, når informanterne omtalte deres egne familjemedlemmer (mamma, mamman, omma, omman, abbi, abbin osv. 'mor', 'bedstemor', 'bedstefar'). Hun siger bl.a., at de bestemte dialektale former i høj grad var blevet afløst af de ubestemte standardformer i 1980- og 1990-generationen. Denne konklusion bygger hun på afkrydsningsskemaerne. Den ubestemte standardform var den mest almindelige blandt børnehavebørn i Sandur (Johannesen 2005, s. 29).

Johannesen siger, at der er stor aldersmæssig variation i anvendelsen af de personlige pronominer (variabel 2). Hun påpeger en ændring fra dialektale pronominer henimod standardformer, dvs. fra [o:gon, $\left.\mathrm{t}^{\mathrm{h}} \mathrm{i}: \mathrm{gvn}\right]>\left[\mathrm{o}^{\mathrm{h}} \mathrm{k}: \mathrm{vn}^{\mathrm{h}} \mathrm{t}^{\mathrm{h}} \mathrm{I}^{\mathrm{h}} \mathrm{k}: \mathrm{v}\right.$ ] <okkum, tykkum> og [o:gara, $\mathrm{t}^{\mathrm{h}} \mathrm{i}$ :gara] $>$ [ ${ }^{\mathrm{h}} \mathrm{k}$ :ara, $\mathrm{t}^{\mathrm{h}} \mathrm{I}^{\mathrm{h}} \mathrm{k}$ :ara] <okkara, tykkara>. Ifølge hende begynder denne ændring med 1980-generationen, men der er stor inter- og intraindividuel variation. Hun gengiver en lærer i børneskolen, som siger, at af de tyve børn i 3. og 4. klasse anvender i hvert fald syv standardformerne [ $\left.0^{\mathrm{h} k}: \mathrm{vn} \mathrm{t}^{\mathrm{h}} \mathrm{I}^{\mathrm{h}} \mathrm{k}: \mathrm{on}\right]$ (Johannesen 2005, s. 29). Men det er ikke dokumenteret i undersøgelsen. Der er ikke nogen oversigt over kort ó (variabel 3), men oplæsningen fra ordlisten viste stor variation, både interindividuel og intraindividuel med varianterne [0] og [œ] i den næststørste bygd på Sandoy, Skopun (Johannesen 2005, s. 23). 
[7] RESULTATER

Efter at have lyttet samtalerne og oplæsningerne igennem flere gange og tjekket afkrydsningsspørgeskemaerne kan vi nu danne os et billede af, hvordan sandoydialekten har det. Ser vi tendenser til afdialektisering blandt øens yngre befolkning? Hvad fortæller disse tre variabler om situationen?

\section{[7.1] Mamman, mamma, omman, omma osv.}

Undersøgelsen viser, at de ubestemte standardvarianter af familjemedlemmer bliver mere brugt end de bestemte dialektformer. Tabel 1 viser denne tendens både i samtalerne og i afkrydsningsspørgsmålene:

\begin{tabular}{|c|c|c|c|c|c|}
\hline & $\begin{array}{l}\text { Samtale } \\
3 .-4 . \mathrm{kl} \text {. }\end{array}$ & $\begin{array}{l}\text { Samtale } \\
9 . \mathrm{kl} .\end{array}$ & $\begin{array}{c}\text { Afkrydsning } \\
3 .-4 . \mathrm{kl} \text {. }\end{array}$ & $\begin{array}{l}\text { Afkrydsning } \\
9 . \mathrm{kl} \text {. }\end{array}$ & I alt \\
\hline Mamma & 39 & 21 & 17 & 11 & 88 \\
\hline Mamman & 3 & 4 & 0 & 3 & 10 \\
\hline Pápi & 1 & 5 & 1 & 1 & 8 \\
\hline Pápin & 4 & 4 & 1 & 1 & 10 \\
\hline Babba & 74 & 19 & 15 & 12 & 120 \\
\hline Omma & 19 & 6 & 16 & 6 & 47 \\
\hline Omman & 2 & 9 & 1 & 8 & 20 \\
\hline Abbi & 9 & 4 & 12 & 7 & 32 \\
\hline \multirow[t]{2}{*}{ Abbin } & 0 & 3 & 4 & 7 & 14 \\
\hline & $\% \quad(\mathrm{~N})$ & $(\mathrm{N})$ & $(\mathrm{N})$ & (N) & \\
\hline Ubest. & 88 (68) & (36) & $88 \quad(46)$ & (25) & \\
\hline Best. Form & $12 \quad$ (9) & $36 \quad(20)$ & $12 \quad(6)$ & (19) & \\
\hline I alt & $100(77)$ & $100(56)$ & $100(52)$ & (44) & \\
\hline
\end{tabular}

TABEL 1: Bestemt og ubestemt form for familjemedlemmer i samtalerne og afkrydsningsspørgsmålene i 3.-4. kl. og i 9. kl.

Tallene i Tabel 1 viser belæggene på varianterne. Vi var interesseret i fordelingen af bestemt og ubestemt form, når det gjaldt ens egen mor, far osv. Da babba ikke kan forekomme i bestemt form, må vi se bort fra den i sammentællingen nederst i tabellen. Det generelle billede viser, at de gamle bestemte dialektformer står yderst svagt. Aldersdimensionen viser, at de yngste elever bruger mere standardformerne end de ældste. Denne forskel ses tydeligt i variablerne mamma/mamman, omma/omman og abbi/abbin både i samtalerne og i afkrysningerne. I 9. kl. er der en lille overvægt af dialektformen omman både i samtalerne 
og afkrydsningerne. Forskellen er ikke så stor i formalitetsdimensionen (samtalerne overfor afkrydsningerne). Formerne pápi og pápin er stort set udkonkurreret af babba. Ifølge Johannesen begyndte variationen mellem bestemt og ubestemt form hos personer, som var født omkring 1980 og 1990, dvs. hos dem, som var mellem 15 og 25 år, da hun lavede sin undersøgelse. Resultaterne fra vores undersøgelse i 2019 går i retning af større standardisering af denne variabel. Men vi kan ikke se bort fra, at der kan være tale om et livsfasefænomen. Svaret ligger og venter på fremtidige undersøgelser.

Blandt niendeklasseelever ser vi samme tendens som blandt de yngste: De bruger ubestemte former mere end de bestemte. Denne tendens er særlig tydelig i variationen mellem mamma og mamman, hvor den ubestemte form forekommer 21 gange, mens den bestemte form forekommer fire ganger. Der er flere eksempler på standardformer i den yngste aldersgruppe. Dette mønster ser vi også i Johannesens undersøgelse, hvor fem af syv informanter, som var født i 1990 (dvs. 15 år på det tidspunkt), anvendte ubestemte former (Johannesen 2005, s. 29). Formålet med at sammenligne tallene er delvis at undersøge, om der er overensstemmelse mellem på den ene side sprogbrugen i de frie samtaler og afkrydsningsspørgsmålene, dels at undersøge, om der er forskelle mellem aldersgrupperne. Når to forskellige metoder anvendt på de samme informanter viser lignende mønstre, kan det indikere, at mønstrene ikke er betinget af metoden og kan derfor anses som pålidelige.

\section{[7.2] Personlige og possessive pronominer}

I de personlige pronominer i 1 . og 2. pers. i akkusativ og dativ flertal samt possessivformerne afviger sandoydialekten fra centralfærøsk. Det drejer sig i 1. pers. om dialektformerne [o:gon] <okum> (akk., dat.) og possessiven [o:ga.ra] $<$ okara> på den ene side over for centralfærøsk [ $\left.{ }^{\mathrm{h}} \mathrm{k}: \mathrm{vn}\right]<\mathrm{okkum}>$ og [ ${ }^{\mathrm{h}} \mathrm{k}:$ a.a] $<$ okkara>, og 2. pers. med dialektformerne [ $\mathrm{t}^{\mathrm{t}}$ i:gon] $<$ tykum> (akk. og dat.) og pos-

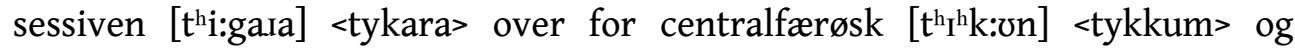
[ $\left.\mathrm{t}^{\mathrm{h}} \mathrm{I}^{\mathrm{h}} \mathrm{k}: \mathrm{a} a \mathrm{a}\right]<$ tykkara>. Spørgsmålet er, om vi kan se den samme tendens, som Johannesen kunne konstatere, at de lokale former viger for standardformerne (Johannesen 2005, s. 29).

Vi kan ikke sammenligne brug af pronomenformerne på tværs af aldersgrupperne i samtalerne i vores undersøgelse, da disse af en eller anden grund stort set var fraværende i den ældste aldersgruppe. I stedet for kan vi kigge på fordeling mellem dialektformerne og standardformerne i 3.-4. klasse. Fordelingen er vist i tabel 2: 


\begin{tabular}{|c|c|c|c|c|c|c|}
\hline \multirow{2}{*}{\multicolumn{2}{|c|}{$\begin{array}{c}\text { [o:gon] } \\
13\end{array}$}} & \multirow{2}{*}{ 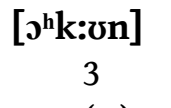 } & \multicolumn{2}{|c|}{ [t'i:gon] } & \multicolumn{2}{|c|}{$\left[\mathbf{t}^{\mathrm{h}} \mathrm{I}^{\mathrm{h}} \mathrm{k}: \mathrm{un}\right]$} \\
\hline & & & & 5 & & 2 \\
\hline$\%$ & $(\mathrm{~N})$ & $\% \quad(\mathrm{~N})$ & $\%$ & $(\mathrm{~N})$ & $\%$ & $(\mathrm{~N})$ \\
\hline 81 & (16) & 19 (16) & 71 & (7) & 29 & (7) \\
\hline \multicolumn{2}{|c|}{ [o:ga.ıa] } & 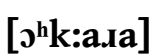 & \multicolumn{2}{|c|}{ [t"ti:ga.ıa] } & \multicolumn{2}{|c|}{ 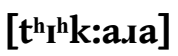 } \\
\hline \multicolumn{2}{|c|}{11} & 3 & \multicolumn{2}{|r|}{5} & & 0 \\
\hline$\%$ & $(\mathrm{~N})$ & $(\mathrm{N})$ & $\%$ & $(\mathrm{~N})$ & $\%$ & $(\mathrm{~N})$ \\
\hline 79 & (14) & (14) & 100 & (5) & 0 & (5) \\
\hline
\end{tabular}

TABEL 2: Variation i de personlige og possessive pronominer i 3. og 4. klasse i samtalerne.

Tallene i næstøverste række er antallet belæg for varianterne. Mønstret er meget klart: De lokale former anvendes mere end de tilsvarende centralfærøske standardformer i samtalerne. Den tendens, som Johannesen kunne konstatere (at standardformerne begyndte at vinde terræn i 1990-årgangen), ser altså ikke ud til at brede sig blandt de 10-årige i det uformelle dagligsprog.

Vi kan nu sammenligne denne variabel på tværs af aldersgrupperne med udgangspunkt i afkrydsningsspørgsmålene. Fordelingen ser vi i figur 2:

\section{Personlige og possessive pronominer}

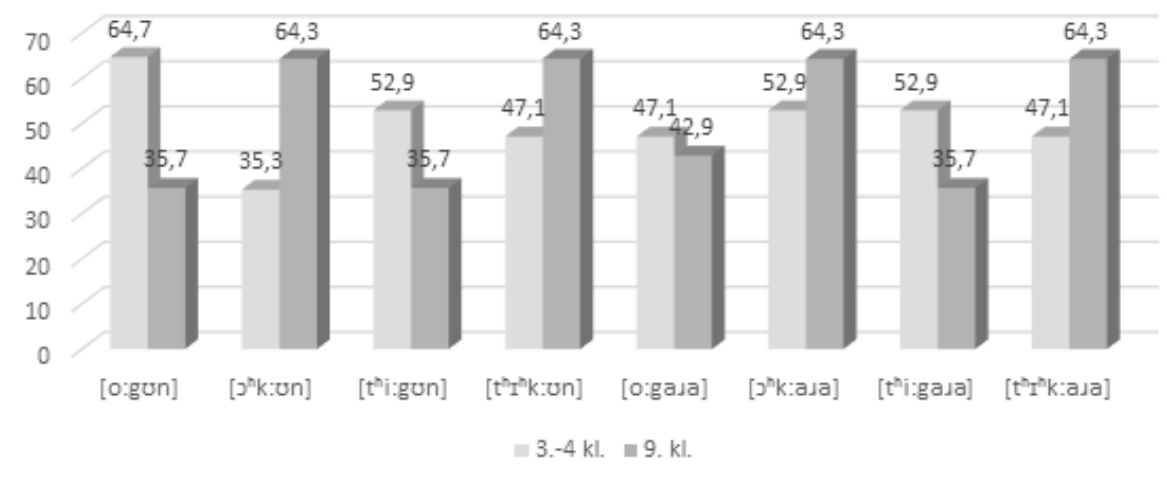

FIGUR 2: Brug af de personlige pronominer i afkrydsningsspørgsmålene i hhv. 3.-4. kl. og 9. kl.

Søjlediagrammet viser den relative fordeling af pronominerne mellem dialektvarianterne og standardvarianterne. F.eks. viser de to første søjlerækker, at dialektformen [o:gon] er langt mere frekvent end standardformen [ $\left.0^{\mathrm{h}} \mathrm{k}:{ }^{\mathrm{on}}\right]$ hos de yngste, hhv. 64,7 \% mod 35,3 \% hos de ældste. Eller udtrykt på en anden måde: 
De ældste elever har i højere grad tendens til at krydse af for de nyere centralfærøske standardformer, som i øvrigt er det generelle billede, vi ser for afkrydsningerne for pronomierne. Dette kan tolkes som resultat af den specielt stærke gruppedannelse blandt teenagerne, hvor sprogændringer hyppigt forekommer (Sandøy 2008, s. 213). Om der er tale om dialektændringer eller et livsfasefænomen kan denne undersøgelse ikke give svar på.

\section{[7.3] Kort ó}

Johannesen siger om kort ó, at det for det meste udtales som [॰] syd for Skopunarfjørður men tilføjer, at i den næststørste bygd på øen, Skopun, er der variation mellem [0] og [œ] (Johannesen 2005, s. 15, 23). Johannesens konklusion er, at ordene tólv 'tolv', fólk 'folk', bóndi 'bonde', bóltur 'bold' udtaler stort set alle med dialektalt [॰], mens ord som f. eks. hósdagur 'torsdag', sólja 'engkabbeleje' og skjótt 'hurtigt, snart' for det meste udtales med [œ]. Tabel 3a-b viser variationen af kort ó i de frie samtaler og i oplæsningen fra ordlisten. Alle forekomster er talt med. Det er umuligt at sammenligne aldersgrupperne i de frie samtaler, da forekomsterne er så forskellige i antal. Grunden er, at samtalerne netop var frie, så derfor kunne eleverne tale om det, de havde lyst til. På den anden side kan vi sammenligne oplæsningerne mellem aldersgrupperne, da alle læste de samme ord op. I tabel $3 \mathrm{a}-\mathrm{b}$ ser vi fordelingen af kort ó i begge aldersgrupper:

\begin{tabular}{|c|c|c|c|c|}
\hline \multicolumn{5}{|c|}{$3 .-4 . \mathrm{kl}$. } \\
\hline & \multicolumn{2}{|c|}{ Samtale } & \multicolumn{2}{|c|}{ Oplæsning } \\
\hline & [0] & [œ] & [0] & [œ] \\
\hline pige, pige & 4 & 0 & 16 & 2 \\
\hline pige, pige & 7 & 0 & 5 & 12 \\
\hline dreng, dreng, pige & 7 & 0 & 8 & 18 \\
\hline pige, dreng & 5 & 0 & 14 & 4 \\
\hline pige, dreng & 7 & 0 & 16 & 1 \\
\hline pige, pige & 9 & 3 & 9 & 8 \\
\hline dreng, dreng & 7 & 0 & 11 & 6 \\
\hline N belæg i alt & 46 & 3 & 79 & 51 \\
\hline$\%$ & 94 & 6 & 61 & 39 \\
\hline
\end{tabular}

TABEL 3A: Udtale af kort ó i de to aldersgrupper i samtaler og oplæsning. 


\begin{tabular}{ccccc}
\hline & \multicolumn{2}{c}{ 9. kl. } & \multicolumn{2}{c}{ Oplæsning } \\
\hline & [o] & [œ] & [o] & [œ] \\
dreng, dreng & 4 & 10 & 4 & 14 \\
dreng, dreng & 2 & 0 & 18 & 0 \\
dreng, dreng & 16 & 0 & 18 & 0 \\
dreng, dreng & 2 & 2 & 4 & 14 \\
dreng, dreng & 0 & 0 & 11 & 5 \\
pige, pige & 3 & 2 & 7 & 11 \\
pige, pige & 2 & 0 & 14 & 4 \\
N belæg i alt & 29 & 14 & 76 & 48 \\
\% & 67 & 33 & 61 & 39 \\
\hline
\end{tabular}

TABEL 3B: Udtale af kort ó i de to aldersgrupper i samtaler og oplæsning.

Første kolonne i hver aldersgruppe angiver kønssammensætningen i de syv gruppesamtaler. Oplæsningen foregik enkeltvis, dog med et par undtagelser (se foran). Tallene i den tredjenederste række viser det samlede antal belæg for hver af varianterne af ó-variablen, og den nederste række viser det samlede belæg på variablen samt den procentuelle fordeling mellem varianterne. Tabellen viser, at dialektudtalen er mere frekvent end standardudtalen såvel i samtalen som i oplæsningen i begge aldersgrupper. Men tallene i den yngste aldersgruppe viser et tydeligere mønster i samtalerne i forhold til den ældste aldersgruppe. Stort set alle de yngste elever har [o]-udtale (46 i alt); kun tre elever har [œ]-udtale. I den ældste aldersgruppe er mønstret noget anderledes: af de 43 forekomster af denne variabel er 14 med standardudtale (tallene er hhv. 29 og 14). Det betyder, at en forholdsvis større andel af de ældste elever har standardudtale.

Fordelingen mellem dialektformen [0] og standardformen [œ] i oplæsningen viser det samme mønster i begge aldersgrupper: 79/51 hos de yngste og 76/48 hos de ældste. Det ser ikke ud til at være nogen kønsforskelle. En årsag til de forholdsvis mange forekomster af standardformer i oplæsningen kan være, at eleverne har været bevidste om forskellen mellem dialekt og standard og har valgt den mere statusprægede standardform. Denne påstand siger ikke noget om dialektændringer, men kan afdække noget om holdninger til dialekt og standard blandt de yngste sprogbrugere på øen: dialekt i uformel samtale og mere standard i læseudtalen. Når vi undersøger, hvordan varianterne er fordelt på de forskellige ord i oplæsningen, får vi det resultat, som ses i tabel $4 a-b$. Tabellen skal læses således, at af de 134 belæg på variablen kort ó udgør dialektvarianten $47 \%$ og standardvarianten 53 \% hos de yngre. De tilsvarende tal i den ældste 
aldersgruppe er, at af de 123 belæg udgør dialektvarianten $61 \%$ og standardvarianten $39 \%$. Tabellen viser i øvrigt stor variation i oplæsningen, både indbyrdes i aldersgrupperne og aldersgrupperne imellem. Hos de yngste vinder dialektformen [0] fire gange over standardformen [œ] i fólk, bóndi, bóltur, skjótt. I den ældste aldersgruppe vinder dialektformen [0] fem gange over standardformen i fólk, bóndi, bóltur, stórt, tólv. De tre dialektale 'gengangere' i begge aldersgrupper er fólk, bóndi og bóltur. Her ser vi samme tendens, som Johannesen påpeger, nemlig at ordene hósdagur, sólja og skjótt udtales med standard [œ] (Johannesen 2005, s. 15). Vi kan dog ikke bruge denne sammenligning som eksempel på sprogændring i virkelig tid, fordi der er tale om to forskellige grupper af informanter. Men de kan tolkes som sprogændringer i tilsyneladende tid.

\begin{tabular}{|c|c|c|c|c|}
\hline \multicolumn{5}{|c|}{ 3. $-4 . \mathrm{kl}$. } \\
\hline Variabel & [0] & Antal & [œ] & Antal \\
\hline fólk & folk & 10 & fœlk & 4 \\
\hline stórt & stort & 5 & stœrt & 9 \\
\hline tólv & tolv & 7 & tœlv & 9 \\
\hline bóndi & bondi & 9 & bœndi & 7 \\
\hline bóltur & boltur & 10 & bœltur & 5 \\
\hline hósdagur & həsdeavor & 4 & hœsdcavor & 11 \\
\hline sólja & solja & 2 & sœlja & 13 \\
\hline skjótt & $\int \mathrm{o}^{\mathrm{h}} \mathrm{t}:$ & 9 & $\int œ^{h} t:$ & 5 \\
\hline dóttir & dot:ir & 7 & dœht:ir & 8 \\
\hline $\mathrm{N}$ i alt & & $63 / 134$ & & $71 / 134$ \\
\hline$\%$ & & 47 & & 53 \\
\hline
\end{tabular}

TABEL 4A: Oplæsning fra ordliste i 3.-4. og 9. kl. 


\begin{tabular}{|c|c|c|c|c|}
\hline \multicolumn{5}{|c|}{$9 . \mathrm{kl}$. } \\
\hline Variabel & [0] & Antal & [œ] & Antal \\
\hline fólk & folk & 11 & fœlk & 3 \\
\hline stórt & stort & 10 & stœrt & 5 \\
\hline tólv & tolv & 12 & tœlv & 2 \\
\hline bóndi & bondi & 9 & bœndi & 4 \\
\hline bóltur & boltur & 9 & bœltur & 3 \\
\hline hósdagur & hosdeavor & 6 & hœsdeavor & 8 \\
\hline sólja & solja & 6 & sœlja & 8 \\
\hline skjótt & $\int \mathrm{O}^{\mathrm{h}} \mathrm{t}:$ & 6 & $\int \aleph^{h t:}$ & 8 \\
\hline dóttir & d $\jmath^{h t}: i r$ & 6 & dœht:ir & 7 \\
\hline $\mathrm{N}$ i alt & & $75 / 123$ & & $48 / 123$ \\
\hline$\%$ & & 61 & & 39 \\
\hline
\end{tabular}

TABEL 4B: Oplæsning fra ordliste i 3.-4. og 9. kl.

\section{[8] KONKLUSION}

To af de tre variabler, som omtales i denne artikel, viser mere brug af dialektvarianterne end af standardvarianterne. Dialektformerne af de personlige og possessive pronominer anvendes mere end de tilsvarende standardformer i den yngste aldersgruppe. Der er stor variation i udtalen af kort ó, især hos de ældste elever, hvor fordelingen viser, at dialektudtalen er mere frekvent end standardudtalen såvel i samtalen som i oplæsningen i begge aldersgrupper. På den anden side viser variablen familjemedlemmer, som egentlig består af flere variabler, tydeligt, at især den yngste aldersgruppe foretrækker standardformerne frem for dialektformerne. Den variant, som står svagest blandt familjemedlemmerne, er dialektformen mamman. Undersøgelsen viser således både stabilitet og ændring i dialekten blandt børn og unge på Sandoy. Stabilitet ser vi f.eks. i brugen af de dialektale personsfornavne og possessiver, mens de to andre variabler indikerer ændringer. Hvad der vil ske med dialekten i fremtiden ved vi naturligvis ikke, men med denne undersøgelse er der lagt et fundament for fremtidige dialektundersøgelser i virkelig tid, og det er ikke så lidt enda.

TAK

Kære Janne, tak for mange uforglemmelige minder fra feltarbejdet i nordisk dialektsyntaks på Færøerne i 2008, hvor du var en af drivkræfterne.

Jeg vil også gerne takke mine anonyme fagfæller for en kritisk og konstruktiv gennemgang af artiklen. 


\section{LITTERAT UR}

Bugge, Edit \& Jógvan í Lon Jacobsen. 2018. Hugburður til variatión í føroyskum talumáli. Íslenskt mál og almenn málfrceði, 40: 97-117.

Johannesen, Ásleyg. 2005. Sandsmál - eitt mál í broyting. BA-afhandling på Institut for færøsk, Færøernes Universitet. Ikke publiceret.

Petersen, Hjalmar P. 1996. Vágamálføri. Fróðskaparrit, 44. Bók: 5-21.

Petersen, Niels Reinholt. 2001. Elemetær statistik. København: Institut for almen og anvendt sprogvidenskab.

Sandøy, Helge. 2008. Språkendring. I Språkmøte. Innføring i lingvistikk, redigeret af Britt Mæhlum, Gunnstein Akselberg, Unn Røyneland \& Helge Sandøy, s. 195219. Oslo: Cappelen Akademisk Forlag.

Weyhe, Eivind. 2012. Bendingarmunur í føroyskum málførum. Eivindaródn. Greinar 1979-2011, 374-419. Fróðskapur. Tórshavn: Faroese University Press.

\section{SUMMARY}

In this article, dialect changes and variation among young schoolchildren in the island of Sandoy in the Faroe Islands are discussed. The fieldwork was made by a group of students at the University of the Faroe Islands in November 2019 under the guidance of this article's author. The informants are two groups of 10 and 15 year old schoolchildren. By examining the young generation, we can get information about the 'state of health' of the dialect. Here three dialectal variables are examined: (i) The variation of definite and indefinite form of words for family members, for instance the dialectal form mamman 'the mother' and the Central Faroese form mamma 'mother'; (ii) Personal and possessive pronouns in 1st and 2nd person plural in oblique case, for instance the dialect form [o:gon] <okum> 'us' and the Central Faroese form [ $\left.0^{\mathrm{h}} \mathrm{k}: \mathrm{on}\right]<\mathrm{okkum}>$ 'us'; (iii) The pronunciation of short ó with the dialectal variant [o] and the Central Faroese form [œ], for instance [folk] resp. [fœlk] <fólk> 'people'.

The first variable shows clearly a tendency towards dialect change in the young generation: the indefinite forms are much more frequent than the dialect counterpart. The use of the pronouns shows a relatively high degree of variation: the dialect forms are more frequently used by the 10 than the 15 year old pupils. The pronunciation of short ó shows variation to a large extent. Here we see the same pattern as we saw for variable 2: the youngest pupils are more likely to use the dialectal form [0] than the older ones. On the other hand, variation is much more common in the group of 15 year old pupils. 
This study shows both stability and change in the dialect of children in Sandoy: Stability in use of the dialectal forms of the personal and possessive pronouns, and variation and change in the two other variables. In a couple of years an underwater tunnel will connect the island of Sandoy with the central part of the islands. In a future scenario this dialect study opens the possibility for comparative studies of the dialect of Sandoy before and after the opening of the tunnel. 
